\title{
LIBERALIZATION OF ECONOMIC DEVELOPMENT AS A DRIVER OF ECONOMIC GROWTH AND COMPETITIVENESS OF UKRAINE'S ECONOMY
}

\author{
OLENA NESTERENKO \\ $\mathrm{PhD}$ in Economics, Associate Professor \\ Taras Shevchenko National University of Kyiv, Ukraine \\ Laureate of the State Prize of Ukraine in the field of science and technology \\ nesterenkoo@knu.ua
}

KEYWORDS: ORTHODOX NEOCLASSICAL THEORY, NEOLIBERAL ECONOMIC THEORY, LIBERALIZATION OF THE ECONOMY, ECONOMIC FREEDOM, INSTITUTIONALIZATION OF ECONOMIC INTERACTIONS, INDEX OF ECONOMIC FREEDOM.

For citation: Nesterenko, O. (2019). Liberalization of Economic Development as a Driver of Economic Growth and Competitiveness of Ukraine`s Economy, Globalization And Business, №8, pp. 77-82. https://doi.org/10.35945/gb.2019.08.008

The issue of increasing competitiveness and innovative economic development, given its extraordinary relevance and significance, naturally occupies a prominent place among modern economic research. At the same time, there have not been any significant changes in real growth rates in Ukraine in recent years: after a critical fall in real GDP growth in 20142015 , against the backdrop of active military actions and the imbalance in the foreign exchange market and financial relations, growth has been restored, however, at an extremely moderate pace - close three percent annually, in particular $2.4 \%, 2.5 \%$ and $3.3 \%$ respectively in 2016-2018 (State Statistics Service of Ukraine: official site). Forecasts for the current year also do not show significant breakthroughs, as it is supposed to slow down real GDP growth to $2.5 \%$ in 2019 (National Bank of Ukraine: official site).

Neoclassical and Neo-Keynesian approaches to economic growth research, common in economic theory from the second half of the last century, are now perceived by the scientific community as traditional. The first of them continues to use the methodological apparatus of the neoclassical production function and consistently broadens the list of factors of economic growth, thus trying to answer the actual challenges of modern economic life. Another approach, the Neo-Keynesian, based on the concepts of efficient aggregate demand and multiplier expansion, is based on the recognition of the leading role of investment spending, initiated primarily by public decisions, and not by private business (Dequech... 2007). According to the logic of the Neo-Keynesian models, "gaps" in private sector investment activity must be offset by state-sponsored or stimulated state investments that can fulfill the role of driver of economic progress.
The purpose of the article is theoretical substantiation of the necessity of liberalization of socio-economic development on the principles of philosophical and methodological principles of neo-liberal economic theory and disclosing ways of practical implementation of neoliberal guidelines in the context of stimulating economic growth and competitiveness of the Ukrainian economy. In turn, the need for liberalization of the Ukrainian economy is closely correlated with the restoration of the reputation of the neo-liberal economic doctrine as a whole.

The subject of the study is the ontological and epistemological dimensions of economic freedom in the context of its impact on socio-economic development.

The objective of the study is the process of liberalizing economic development in a national and global scale.

Actualization of the tasks of increasing competitiveness and providing a qualitatively new innovative impetus has been realized, in particular, in the study of "the most fundamental and urgent problems of world development - ensuring sustainable and stable growth of the world economy" (The Sveriges Riksbank Prize in Economic Sciences in Memory of Alfred Nobel, 2018). It is about the award of the Alfred Nobel Prize in 2018 to V. Nordhaus and P. Romer for the study of climate change and technological innovation in the long-term macroeconomic analysis. The wording of the Nobel Committee reflects the recognition of the need for a continuous search for new factors and factors for economic growth, including climate change, new technologies, environmental aspects of economic activity, etc.

In our opinion, solving the tasks of strengthening competitiveness and innovative type of growth can be realized 
on the basis of the potential of liberal and neo-liberal guidelines that have undergone a long-term review in developed economies. In the transitional, emerging economies, the ideological concept of neoliberalism can become the basis of socio-economic progress in several areas. Among the main ones is the realization and maintenance of economic freedom and responsibility, the rejection of the paternalistic type of state, the formation of a powerful and rigid institutional framework and certain "rules of the game" in the economic space.

According to our belief, theoretical representations and real actions of the reformers of the socio-economic systems of the last decades of the last century were in the plane of the orthodox neoclassical theory. This was facilitated by the development and implementation by developed countries of a United States-led recommendation package, known as the Washington Consensus. Consciously or unconsciously, a profound substitution of the concepts, according to which the opinions were spread, was carried out that the neoliberal economic theory served as the basis for the adopted recommendations. The dislocation of the neoliberal theory was also facilitated by the fact that reformist rhetoric indeed contained leading neo-liberal ideas.

In fact, the basis of the adopted recommendations of the Washington consensus was the ideas and conclusions of the theories of monetarism, the economy of supply and rational expectations, which together formed the core of economic neo-conservatism (History... 2015). As you know, neoconservative economic theories in the pre-historic period represented the ideas of economic orthodoxy - a dominant paradigm that largely imitated the neoclassical economic theory. The Washington Consensus was implemented by international financial institutions, including to address the economic development problems of transitional post-socialist and post-Soviet countries, which were forced to comply with its recommendations in exchange for loans, primarily the International Monetary Fund.

"Indicative set" of the recommendations of the Washington Consensus: large-scale privatization of state property, maximum increase in the level of openness of economies, total liberalization of pricing and currency regulation, reduction of budget expenditures, refusal of state support of the real sector and implementation of social programs. The economic policy that became the consequence of the intellectual domination of the neoclassical orthodoxy was devastating for transition economies, since in the absence of relevant market institutions and developed market infrastructure, the formation of deformed quasi-market structures became the consequence of its implementation.

The postulates of the neoclassical theory, in particular the practical embodiment of the ideas of social constructivism (Rothbard, 1979), proved to be disastrous for Ukraine and other countries. Privatization has become a kind of distributive mechanism through which the concentration of the most effective state-owned enterprises in the hands of people close to power, officials, party functionaries, former businessmen, and criminality has been carried out. The extremely dangerous mechanism of initial accumulation of capital was launched, accompanied by negative social consequences: an increase in the income differentiation of the population, the lack of a middle class, poverty, the criminalization of society, the growth of corruption, and others.

Thus, the concepts of radical economic reform were developed, propagated and implemented by leading representatives of the prevailing neoclassical orthodoxy, far from the knowledge of the neo-liberal economic tradition. According to neoliberals, radical reform will never provide the right results, since the total reorganization of a modern, difficultly organized society under the foregoing schemes is doomed to failure. Planning for reforms is imperfect because of the limited human knowledge and the objective impossibility of concentration of information in a single center (Block, 1991). At the same time, conscious actions for the improvement of institutions of expanded order are possible, since each institution must be subjected to rational criticism and remain open to attempts to improve it. At present, the problems of global uncertainty and information "depths" of economic development are significantly increasing (Tokmazishvili... 2018).

The essence of the liberalization of social and economic development lies in the movement towards economic freedom in the broadest sense. The main ideological and philosophical content of liberalization is the strengthening of human-centeredness of the socio-economic system, the restoration of the transparency of economic relations, the strengthening of the humanization of the economic space, and ensuring a clear institutionalization of interactions between all economic actors. The liberalization of the modern economic system is a reflection of the objective patterns of modern economic development, and is also supported by an active policy of supranational structures and international organizations that realize the subjective beginning of this process. Further liberalization of social and economic life is greatly enhanced by modern globalization processes.

An extremely primitive interpretation of liberalism as a state's non-interference in economic life and the implementation of the "policy of free trade" must go back to the past. Note that absolute, "pure" liberalism has not been realized in any of the economic systems that call themselves modern market or mixed. Just as the notion of capitalism of free competition (market economy), it is a peculiar fetish, an ideal model. Therefore, there is a logical question: what is the intellectual value of a liberal tradition and what is our commitment to the ideas of the consistent liberalization of economic relations?

True, true neo-liberal tradition is based on the understanding of man as a self-sufficient value, recognizes the priority of human action, self-esteem, self-actualization and self-improvement of man. All these "self-" do not arise in an isolated environment, they are based on the interaction of individuals, their mutual respect, mutual understanding and mutual support. In this sense, the neo-liberal tradition does not close in the circle of individual intentions and actions, it studies and promotes the creation of an institutional environment, coordinated with priority individualistic principles, with mutually beneficial and responsible activities, primarily economic (Galchinsky, 2011).

The movement towards economic freedom as the pri- 
mary content of liberalization in the economic sphere should be based on ensuring the foundations of competitive access to economic resources, lack of discrimination, respect for property, deregulation of certain spheres of economic life, increased responsibility of economic actors, transparency of economic processes. In the modern world, the key indicator of the level of economic liberalization is played by the integrated index of economic freedom, which assesses the level of real support for economic freedom by the relevant institutions and policies of the countries.

Annual studies of the famous Canadian think tank Fraser Institute (Gwartney, 2016; Hall... 2014; James Gwartney... 2018) provide a fairly objective assessment of economic freedom by comparing aggregate groups of indicators that characterize the size of government (government consumption, state entrepreneurship and investment), the legal system and the protection of property rights, the reliability of the monetary system, the freedom of international trade and the system of regulation of markets and business. The most free countries (first quartile rating) show higher per capita income, higher rates of economic growth and higher life expectancy. We observe a contradiction, which once again proves the correctness of our judgments: if Ukraine were to have genuine liberalization, it would be unlikely that the country would be in the fourth quartile (the least free countries) in terms of the index of economic freedom. Thus, in the 2016 report, the country ranked 135th out of 159 countries (Gwartney, 2016).

The report's figures for 2017 were even more disappointing: Ukraine ranked 149th out of 159 countries, losing 14 positions over the previous year. In addition, in the reports 2016 and 2017 Ukraine was the only European country in the last quartile. In the 2018 report, the situation somewhat stabilized - Ukraine ranked 134th out of 162 countries in the world. The position has improved somewhat by reducing the size of the government and improving the regulation of the credit market (James Gwartney... 2018).

The latest Economic Freedom in the World report, published in 2018, provides detailed data on 162 countries and territories on the basis of a flexible and continuously improved methodology for calculating the Economic Freedom Index, and is based on the ranking of countries in terms of economic freedom. The Integrated Index of Economic Freedom is calculated on the basis of 42 indicators that represent a combination of sources and factors for the expansion or limitation of the impact of state policy and institutions on the economic freedom of individual countries.

The integral index of economic freedom combines a system of indicators that measure the levels of economic, political and institutional support for economic freedom in the world. The methodology and the methodology for calculating the indicators are unified, based on objective criteria, because in this index actually do not use surveys, expert opinions, subjective impressions, etc. Instead, the correctness and comparability of the results are ensured, which, in their turn, allows them to be widely used for scientific, research and business purposes.

In our opinion, the integral index of economic freedom has not only theoretical and methodological value, but also reflects the practical value of the study of the degree of stimulation or restriction of economic freedom. This is explained by the fact that the indicator measures the non-idealized, exemplary situation of liberal development and assesses the level of liberal orientation of world politics, while attempting to assess the level of real support for economic freedom by the relevant institutions and policies of countries.

The "Size of Government" (first block of indicators) assesses existing restrictions and probable threats to economic freedom. The logic of this group of indicators is clear, since the growth of government expenditures, procurement, taxes, and the number of enterprises belonging to the public sector significantly restricts economic freedom (Hall... 2014). In the end, the free personal choice of consumers and producers is substantially limited by state actions, the adoption of appropriate decisions by the state authorities. Indicators on the basis of which the size of the state is calculated in the economy are the volume of state consumption, state transfers and subsidies, the size of state investments and the number of state-owned enterprises (Buchanan, 2004). In addition, when determining the size of government, the highest marginal tax rates are taken into account, including the highest marginal tax rates on income and wages. The launch of ProZorro's transparent ProZorro Procurement system in Ukraine and a substantial reduction in the Single Social Contribution (CSP) allowed the country to improve this ranking of indicators. So, ProZorro is a hybrid electronic open source government e-procurement system created as a result of a partnership between business, government and civil society (State Statistics Service of Ukraine: official site).

"Legal System And Protection Of Property Rights" (second group of indicators) assesses the foundations of the economic-legal system, its level of civilization, the degree of economic freedom and the availability of civil society. The indicators of this group include: inconsistency of the legislation, independence and impartiality of the judicial branch of power and justice, the reliability of the work of law enforcement bodies, as well as the assessment of the possibilities of interference of law enforcement agencies in the administration of justice and in political processes. In this block, in particular, the degree of influence on the economic freedom of the business entities formed in the state is taken into account, by assessing the principles of law enforcement in relation to contracts, the regulatory value of real estate purchase transactions, business losses from crime, etc. In the past year, this group has replenished with a new index - the index of gender inequality. However, the most important was and remains the index of protection of property rights, in fact, the protection of individuals and their legally acquired property. Researchers at the Fraser Institute, as well as representatives of the neoliberal trend, consider this function as the most important function of the government. It should be noted that it is the most vulnerable in the period of economic transformations, including in Ukraine. The contradictory nature of the legislation, the impartiality of the judiciary, the possibility of pressure on court decisions on the part of the power, business and state structures are realities of the Ukrainian economy 
that make it impossible to improve positions in the rating of economic freedom for this block.

The aggregate of indicators of the third group "Reliable Money" is the smallest in number, but it is extremely important. Indicators integrated assess the growth of money supply, inflationary developments over the past year and the deviation of inflation, as well as the possibility of opening bank accounts in foreign currency. Given that inflation reduces the value of all incomes and savings of all categories of the population without exception, the critical importance of reliable money for the protection of property rights has been emphasized. In situations of high and volatile inflation, individuals suffer from loss of income, planning their future is much worse, and less efficiently implementing their economic freedom. The transition to the inflation targeting regime in Ukraine took place, however, rather painfully, by a significant devaluation of the national currency in 2014. In addition, significant restrictions on foreign exchange transactions were maintained until the end of 2018, when the liberalization of foreign exchange operations was regulated (National Bank of Ukraine: official site, 2019).

The next set of indicators (fourth) reflects the freedom of international trade in the sense of freedom of exchange in a broad sense, that is, the possibility of buying, selling, concluding contracts in a situation where freedom of exchange applies to enterprises and individuals in other countries. Consequently, freedom of trade at the international level means free exchange across national borders. In today's globalized world, the freedom of international trade is a vital element of economic freedom. If governments implement protectionist policies, even on a limited scale, they reduce the ability of citizens to engage in voluntary exchanges with other countries, that is, they reduce economic freedom. The indicators of this group measure a large range of trade restrictions: tariffs, including average tax rates and foreign trade tax revenues; quotas; hidden administrative restrictions; regulatory and non-tariff barriers to trade. It also takes into account the actions of the state aimed at controlling the exchange rate, the movement of capital and labor, restrictions on foreign ownership and investment, estimated cost of observance of normative requirements for export-import operations. High ratings in this group are only possible with low customs tariffs, transparent and efficient administration of customs procedures, freely convertible currency, and also "weak" control over the movement of material, human and other types of capital. At present, the progress towards liberalization of the movement of all types of capital and the transparent administration of customs duties is insignificant.

The last group - "Regulation" - uses a set of indicators that assess the internal, endogenous direction of government regulation. We are talking about the burdens of regulations, restrictions on the rights of exchange and trade within the country, complications with obtaining loans, employment, obstacles to managing their own businesses. The indicators of the fifth group determine how regulatory regulations restrict access to markets, impede the freedom of voluntary exchange, and reduce the level of economic freedom. It is about limiting the freedom of exchange in the market of credit resources, in particular in the aspect of private sector lending and interest rate control; regulation of the labor market, including taking into account the rules of employment, the cost of dismissal of the employee, the minimum wage, the flexibility of procedures for recruitment and release, the rigidity of procedures for the conclusion of collective agreements. The conditions and consequences of direct business regulation are also taken into account: administrative requirements, licensing restrictions, bureaucracy costs, business start-up costs, additional payments and bribes, and the cost of complying with tax laws. The high level of the shadow economy, the significant corruption of economic relations in Ukraine, the widespread traditions of tax evasion do not allow to improve the existing position in the rating.

Together with such disappointing assessments, there are few examples of the gradual expansion of the liberalization of the Ukrainian economy, in particular by implementing measures to implement the Association Agreement between Ukraine and the EU. Among such measures are the formation of competitive markets, equal access to the infrastructure of all market participants, the liberalization of entrepreneurial activity, the formation of a favorable institutional environment for licensing and licensing regulation. Such liberalization should take place on the basis of neo-liberal doctrine, in particular the completeness and accessibility of information, transparency, communication, and responsibility. Among modern examples of liberalization of the Ukrainian economy are deregulation of the business environment, liberalization of the intellectual property market, tax reform, easing currency restrictions, and others.

The data released in "Economic freedom in the world" provide an opportunity to analyze the impact of economic freedom on investment, economic growth, income levels and poverty. They also allow you to analyze the effects of restricting economic freedom, the differences in levels of economic freedom between individual countries and the dynamics of respect for the principles of economic freedom. Studies show that countries that have formed the right institutions and pursue policies that promote economic freedom have higher levels of income, wealth, investment, and more rapid economic growth (Gwartney, 2016; Hall... 2014). Among such countries are Hong Kong, Singapore, New Zealand, Switzerland, Ireland, USA, Georgia, Mauritius, Great Britain, Australia and Canada.

Countries with a high index of economic freedom (economically free) show better results than countries with a low economic freedom index (so-called unfair) on many indicators, primarily on welfare indicators. Countries from the upper quartile (the first in the forty countries) show GDP per capita average $\$ 40,376$ compared to $\$ 5,649$ for the lower quartile countries (the latest by forty countries) (measured at purchasing power parity at constant prices in 2011). In the upper quartile countries, the average income of the poorest $10 \%$ of the population was $\$ 10,660$, while in the lower quartile $-\$ 1,345$ (James Gwartney... 2018).

It is significant that other important indicators of socio-economic and humanitarian development also show a correlation with the degree of economic freedom and demonstrate the advantages of more free countries, namely: 
the expected life expectancy is 79.5 years in the countries with the upper quartile of economic freedom and 64.4 years in the lower countries;

the level of observance of political and civil freedoms in economically free countries is much higher;

gender equality is higher in economically free countries;

the level of happiness is much higher in economically free countries (James Gwartney... 2018; United Nations, 2016).

\section{CONCLUSIONS}

Thus, the liberal tradition, regardless of the internal differentiation of the views of the representatives within the limits of classical liberalism or modern neo-liberalism, recognize the axiomatic concept of economic freedom. Liberalization of the economic space means the unhindered realization of the right to free choice, non-discriminatory coordination of economic activity, competition and voluntary exchange, open markets, clear definition, observance and protection of property rights. It is generally acknowledged that individuals and their associations have the right freely to exercise their own economic freedom until their actions do not harass or harm others or their property. The liberalization of economic development is also closely linked to the observance of predetermined rules and norms, the institutionalization of the economic environment, the responsibility of economic actors and the state, and the transparency of economic activity in all spheres. Thus, the primary strategy for reforming Ukrainian and other post-socialist economies ignored the intellectual tradition of the neo-liberal theory, which clearly separates from market fundamentalism and opposes the notions of neoclassical orthodoxy.

Measurement of the integrated index of economic freedom is an attempt to answer the question of how the institutions and state policies of a particular country meet the ideal of a "minimal" state and a "limited" government - the key theoretical concepts of a liberal economic theory. The neoliberal ideal of the place and role of the state (government) in the economic system, which achieves the highest degree of economic freedom, is the following: the protection of property rights, the maintenance of a stable and stable state of the monetary system, non-interference in the economic activities of economic entities, the provision of a limited, " narrow "set of public goods - services of law and order, justice, national defense, as well as the state's implementation of a certain range of social functions.

The positive impact of economic freedom on economic growth, income levels and poverty reduction, investment growth and competitiveness are evidenced, in particular, by the annual comprehensive studies of the Fraser Institute. The economies of those countries in which relevant institutions are formed and the corresponding policy of liberalizing economic relations is being pursued show higher levels of investment, income, welfare and faster economic growth. The negative effects of the restriction of economic freedom in Ukraine are caused by the wrongly chosen model of economic reform, the discrediting of the liberal model of the economy, the harassment of economic freedom and lack of responsibility.

\section{REFERENCES:}

1. Block W. E., ed. (1991). Economic Freedom: Toward a Theory of Measurement. Proceedings of an International Symposium (Volume 2). Fraser Institute.

2. Buchanan J. M. and Musgrave R. A. (2004) Public Finance and Public Choice: Two Contrasting Visions of the State.

3. Dequech D. (2007). Neoclassical, mainstream, orthodox, and heterodox economics. Journal of Post Keynesian Economics, Taylor \& Francis Journals, vol. 30(2), pp. 279-302.

4. Galchinsky A. (2011). Liberalism. Lessons for Ukraine. Kyiv.: Lybid, 288 p. (In Ukrainian).

5. Gwartney J., Lawson R. and Hall J. (2016). Economic Freedom of the World: 2016 Annual Report. Fraser Institute. https://www.fraserinstitute.org/studies/economic-freedom-of-the-world-2016-annual-report

6. Gwartney J., Lawson R., Hall J. and Murphy R. (2018). Economic Freedom Dataset, published in Economic Freedom of the World: 2018 Annual Report. Fraser Institute. <www.fraserinstitute.org/economic-freedom/dataset>.

7. Hall J. and Lawson R. (2014). Economic Freedom of the World: An Accounting of the Literature. Contemporary Economic Policy 32, 1: 1-19.

8. History of economic thought (2011): textbook: teach. manual / ed. V. Bazilevich. Kyiv: Znannya. 1198 p. (In Ukrainian).

9. History of economic thought (2015): textbook: 2 vol. / ed. V. Bazilevich. Kyiv Znannya. (In Ukrainian).

10. National Bank of Ukraine: official site. Inflation Report. January 2019, p.6 URL: https://bank.gov.ua/doccatalog/ document?id=87678886

11. Rothbard, M.N. (1979). Individualism and the Philosophy of the Social Sciences. Cato Institute, San Francisco,

12. State Statistics Service of Ukraine: official site. URL: http://www.ukrstat.gov.ua/

13. State System of Electronic Purchases official site. URL: https://prozorro.gov.ua/en

14. The Sveriges Riksbank Prize in Economic Sciences in Memory of Alfred Nobel 2018 URL: https://www.nobelprize.org/ prizes/economic-sciences/2018/prize-announcement/

15. Tokmazishvili M. The Global Economic Crisis and Economic Science. Globalization and Business. Tbilisi, Georgia. 2018. №5. P. 17-23.

16. United Nations (2016). World Happiness Report 2016 Update. <http:// worldhappiness.report/ed/2016/>. 


\section{LIBERALIZATION OF ECONOMIC DEVELOPMENT AS A DRIVER OF ECONOMIC GROWTH AND COMPETITIVENESS OF UKRAINE'S ECONOMY}

\section{OLENA NESTERENKO}

PhD in Economics, Associate Professor

Taras Shevchenko National University of Kyiv, Ukraine

Laureate of the State Prize of Ukraine in the field of science and technology

nesterenkoo@knu.ua

KEYWORDS: ORTHODOX NEOCLASSICAL THEORY, NEOLIBERAL ECONOMIC THEORY, LIBERALIZATION OF THE ECONOMY, ECONOMIC FREEDOM, INSTITUTIONALIZATION OF ECONOMIC INTERACTIONS, INDEX OF ECONOMIC FREEDOM.

For citation: Nesterenko, O. (2019). Liberalization of Economic Development as a Driver of Economic Growth and Competitiveness of Ukraine`s Economy, Globalization And Business, №8, pp. 77-82. https://doi.org/10.35945/gb.2019.08.008

SUMMARY

For a long time theoretical representations and real actions of the reformers of the socio-economic system were in the plan of the orthodox neoclassical theory. At the same time, reformist rhetoric contained leading neo-liberal ideas, which substantially discredited them. The main task of the author is to restore the reputation of the neo-liberal economic doctrine as a whole and to prove the necessity of liberalizing the Ukrainian economy in particular.

The article reveals the essence of the liberalization of economic life as a movement towards economic freedom in the broadest sense. The main ideological and philosophical content of liberalization is the strengthening of human-centered economic system, the transparency of economic re- lations, the humanization of the economic space, the institutionalization of interactions between all economic actors. In turn, the key economic and political dimension of liberalization can be represented by an integrated index of economic freedom, which assesses the level of real support for economic freedom by the relevant institutions and policies of the countries. The author analyzes the sources and factors of the expansion or limitation of the influence of state policy and institutions on economic freedom, which determine the level of socio-economic development of countries. It has been determined that countries that have formed relevant institutions and policies that promote economic freedom have higher levels of income, wealth, investment and more rapid economic growth. 